ENCYCIOPEDDE Encyclopédie berbère

BERBERE

28-29| 2008

28-29 | Kirtēsii - Lutte

\title{
Lemtouna, Lamtûna, Lemta, Lamta/Ilemteyen
}

\section{S. Chaker}

\section{OpenEdition}

Journals

Édition électronique

URL : http://journals.openedition.org/encyclopedieberbere/324

DOI : 10.4000/encyclopedieberbere.324

ISSN : 2262-7197

\section{Éditeur}

Peeters Publishers

\section{Édition imprimée}

Date de publication : 1 janvier 2008

Pagination : 4364-4365

ISBN : 2-7449-0707-4

ISSN : 1015-7344

\section{Référence électronique}

S. Chaker, « Lemtouna, Lamtûna, Lemta, Lamta/llemteyen », Encyclopédie berbère [En ligne], 28-29 |

2008, document L13, mis en ligne le 01 juin 2013, consulté le 25 septembre 2020. URL : http://

journals.openedition.org/encyclopedieberbere/324 ; DOI : https://doi.org/10.4000/

encyclopedieberbere.324

Ce document a été généré automatiquement le 25 septembre 2020.

(c) Tous droits réservés 


\section{Lemtouna, Lamtûna, Lemta, Lamta/ Ilemteyen}

\section{S. Chaker}

L'examen des sources médiévales arabes, même si elles sont quelque peu ambigües sur ce point, incite à assimiler les Lemtouna (Lamtûna) aux Lemta/Lamța en raison de leur généalogie commune, de leurs localisations très proches (Ouest saharien), et de l'appartenance explicite de ces deux (?) tribus berbères à l'ensemble des nomades sahariens porteurs $d u$ voile. Selon ces sources arabes, ils sont l'une des tribus berbères sahariennes (au sud de l'oued Sous: Sud du Maroc, Sahara occidental et actuelle Mauritanie), fondatrice de la dynastie des Almoravides* ( \pm 1048 à 1146 ; voir EB IV (1987, p. 539-541). Et, conformément au modèle généalogique de l'historiographie arabe de l'époque, leur nom serait issu de celui de leur ancêtre éponyme, Lamț:

«Lamt, l'aïeul des Lamtouna... » (Ibn Khaldûn, I, p. 174);

«Sanhadj et Lamt étaient fils d'une femme nommé Tizki [...] Cette femme devint

l'épouse d'Aurîgh dont elle eut un fils nommé Hoouar. " (Ibn Khaldûn, I, p. 169,

également p. 170) (voir aussi El-Bekrî, p. 310-312).

2 En berbère, leur nom est bien conservé dans la tradition orale et l'ethnonymie touarègues sous la forme : élemtey (sing.), ilemtéyen (plur.) (Ch. de Foucauld 1940, p. 153 et 1951, III, p. 1086-87). Il désigne une petite tribu touarègue de la région Ghât, qui selon de Foucauld :

«... bien que regardée comme touarègue, [elle] ne fait partie ni des Kel-Ajjer, ni

d'aucun des autres groupements touaregs. Elle doit son nom à une femme nommé

Lamtoûna. » (1940, p. 153).

3 À propos de cette Lamtoûna touarègue, de Foucauld ajoute (1940, p. 318) :

«D'après les légendes touarègues, Lamtoûna serait la mère de tous les Touaregs, de la tribu des Ilemtéyen et de certaines tribus berbères établies à Ghadamès et dans le voisinage. »

4 Cette généalogie, en raison même de la forme du nom de la femme-ancêtre, provient certainement des sources arabes et a dû être diffusée par des milieux lettrés qui y avaient accès. 

est très certainement l'écho du souvenir historique d'une intégration, politique et/ou ethno-culturelle (=les nomades sahariens voilés), des ancêtres des actuels Touaregs à l'ensemble Lamtûna/Almoravides. Il est clair qu'il y a une identification interne (Lamtoûna $=$ mère de tous les Touaregs) et externe (Ilemtiyen = Touaregs, pour les Berbères sahariens non touaregs).

7 Et, les sources arabes, en associant Lamt, Tizki [derrière laquelle se cache sans doute la Ti-n-Hinân* des Touaregs Ahaggar*), Aurîgh (Awrił singulier de Ûrayen*, groupe touareg noble des Kel-Ajjer) et Hoouar* (Hawwâr > Haggâr, Ahaggar*), confirme l'existence d'une connexion étroite Lamta-Lemtouna/Touaregs.

\section{BIBLIOGRAPHIE}

EL BEKRI (DE SLANE trad.), Description de l'Afrique septentrionale, Alger, 1913.

FOUCAULD Ch. de, Dictionnaire touareg-français, Paris Imprimerie nationale, 1951-1952, 4vol. Encyclopédie de l'Islam, V, 1978.

FOUCAULD Ch. de, Dictionnaire abrégé touareg-français des Noms propres, Paris, Larose, 1940.

GAUTIER E.-F., Le passé de l'Afrique du nord. Les siècles obscurs, Paris, 1952 (2édition).

IBN KHALDUN (DE SLANE trad.), Histoire des Berbères et des dynasties musulmanes de l'Afrique septentrionale, 4vol. , Paris, 1925-1956.

\section{INDEX}

Mots-clés : Moyen Âge, Touareg, Tribu(s) 